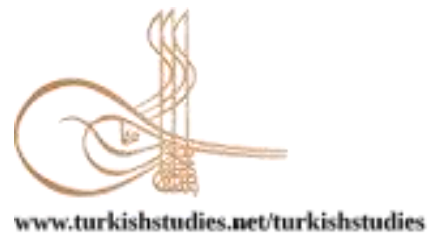

Turkish Studies

eISSN: $1308-2140$

Research Article / Araştırma Makalesi

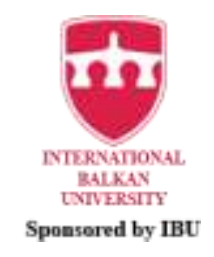

\title{
Cumhuriyet'in On Beşinci Yıl Dönümü Kutlamaları: Başkent Ankara Örneği
}

The Celebrations of the Fifteenth Anniversary of the Republic Day: Capital Ankara Example

\author{
Kadri Unat ${ }^{*}$
}

\begin{abstract}
This article examines the fifteenth anniversary of the capital's celebrations in various dimensions, but especially focuses on the spatial and ceremony. In context the intersection points of the spatial and ceremony duo in the celebrations of the capital city are determined and a panorama of the activities is tried to be created. The adoption of the republican regime is one of the turning point in the Turkish political history. Turkey's, which established as a nation state, new regime was reveal a disengagement from the Ottoman Empire. However it was not easy to orient the society to new era, understanding and regime. Republican People's Party was in need of some symbols for both legitimate the new regime and unity of the society. National days were perhaps the most important of these symbols. The power, which was aware of this fact, immediately took action within the framework of inventing new traditions and started set various special days in the early years. Undoubtedly, the most significant of the special days was the Republic Day. As is known the 29th October was first celebrated in 1924 and accepted as the "National Holiday" with the the legal arrangement in April 19, 1925 and continued to be celebrated every year. Repuclic Day, will not only serve to institutionalize the new regime but also would provide the necessary political environment to reproduction of the new political formation. Therefore, the discourse during the celebrations was inventory in the 1930s. According to our findings, a "High Commission" was established under the chairmanship of Şükrü Kaya to organise of the fifteenth anniversary. Ofcourse the celebrations of the capital city had a special place and importance. Due to the fact that the capital's celebrations would set a model to other provinces and would enable the messages to be given in and out more easily. According to our determinations the Turkish Grand National Assembly, hippodrome, Ulus Square, Victory Monument and Cebeci Martyrdom are stand out in the spatial context. And in the ceremonial context, the reception ceremony which held in the Turkish Grand National Assembly, parade in the hippodrame where everyone attends and where the most spectacular activities were held, the oath of allegiance at the Victory Monument in Ulus Square wich was the city's most frequented place and the activities in which Turkish youth express their gratitude at Cebeci Martyrdom stand out.
\end{abstract}

Structured Abstract: This article examines the fifteenth anniversary of the capital's celebrations in various dimensions, but especially focuses on the spatial and ceremony. In context the intersection points of the spatial and ceremony duo in the celebrations of the capital city are determined and a panorama of the activities is tried to be created. In Turkey, which founded as a nation state, that compatiblewith the spirit of in the 19th century was not easy to transform vassal to citizen. In other words, it was difficult to berak the traditional Turkish society from its old habits, lifestyles and loyalty to the old management understanding.

\footnotetext{
* Dr., Ankara Üniversitesi Türk İnk1lâp Tarihi Enstitüsü

Dr., Ankara University Institute of Turkish Revolution History

ORCID 0000-0003-0200-8463

unatkadri@gmail.com
}

Cite as/ Atıf: Unat, K. (2021). Cumhuriyet'in on beşinci yıl dönümü kutlamaları: Başkent Ankara örneği. Turkish Studies, 16(2), 773-787. https://dx.doi.org/10.7827/TurkishStudies.49164

Received/Geliş: 01 February/Şubat 2021

Accepted/Kabul: 25 April/Nisan 2021

Checked by plagiarism software

Published/Yayın: 30 April/Nisan 2021

CC BY-NC 4.0 
The expectation was to transform the Turkish community shouting from "Long live my Sultan" to "Long Live The Republic" slogans. Only in this way could the ground of social cohesion and political legitimacy be formed. The invention of the Repuclic Day comes across exactly at this point. In chronological context, the first national holiday which officially accepted during the Atatürk era was the April 23 National Sovereignity Day; the second October 29 Repuclic Day; the third August 30 Victory Day and the forth May 19 Youth and Sports Day.

It is possible to handle the Repuclic Day, which is the main theme of our study, in two stages, especially in the Atatürk era. Because the first October 29 celebrations organised in 1924. However, no legal arrangements had made for October 29 yet. October 29 was accepted as the Republic Daywith the regulation which named "National Holiday Law" dated April 19, 1925. And it started to be celebrated every year as a National Holiday.

According to our findings, a "High Commission" was established under the chairmanship of Şükrü Kaya to organise of the fifteenth anniversary. Ofcourse the celebrations of the capital city had a special place and importance. Because the capital's celebrations would set a model to other provinces and would enable the messages to be given in and out more easily. Based on the activities we identified regarding the preparatory phase and celebrations of the fifteenth anniversary. It is quite possible to state that the blessing of the new order is realized through the political symbols produced and spread by the government. Looking at the celebration programme, it is observed that it is an effort to reach all social classes through a strict regulatory but also unifying discourse and organization.

As a result of the fact that the communiity was invited to support the Republic regime and the government. According to our determinations the Turkish Grand National Assembly, hippodrome, Ulus Square, Victory Monument and Cebeci Martyrdom are stand out in the spatial context. And in the ceremonial context, the reception ceremony which held in the Turkish Grand National Assembly, parade in the hippodrame where everyone attends and where the most spectacular activities are held, the oath of allegiance at the Victory Monument in Ulus Square wich was the city's most frequented place and the activities in which Turkish youth express their gratitude at Cebeci Martyrdom stand out. Celebrations and activities are shaped arround the virtues of the founding leader Atatürk and the Repuclig regime cumulatively, aming to create a social memory. Spatial ve ceremonical preferences also make this clear. Execution of the first ceremony in the Turkish Grand National Assembly where national sovereignity is manifested, to highligt the symbolic dimension of the Victory Monument, the Turkish youth to leave a wreath to the monument and swear allengiance to Atatürk and Republic can be considered as important indicators in this framework. This also shows that a leader cult about Atatürk was formed while he was still alive.

As a result, yes, Atatürk could not attend to Ankara celebrations due to his illness. However Ankara looked like a Republic city as it was imagined on the October 13, 1923, when it was determined as the capital city. People from Ankara and those who came from outside of Ankara to participate in the celebrations attented the activities, had fun and integrated with the regime. The regime also fed and strengthened from this. Wasn't it about that from the very beginning that the day of October 29 was invented as a tradition, expressed and symbolized as the "Great Holiday"?

Keywords: Department of Atatürk's Principles and History of Turkish Revolution, Ankara, republic day, National Day, Republic of Turkey, October 29, 1938, the celebrations of the fifteenth anniversary

Öz: Bu çalışma Başkent'te icra edilen on beşinci yıl dönümü kutlamalarını hem hazırlık aşaması hem de etkinlikler boyutuyla incelenmekte, ancak mekân ve tören bağlamına odaklanmaktadır. Bu çerçevede kutlamalar genel anlamda çeşitli boyutlarıyla ele alınmakta, özel anlamda ise mekân ve tören ikilisinin Başkent kutlamalarındaki kesişim noktaları belirlenmekte ve etkinliklerin panoraması oluşturulmaya çalışılmaktadır. Türkiye'de Cumhuriyet rejiminin benimsenmesi, Türk siyasi tarihinin dönüm noktalarından birini oluşturmaktadır. Bir ulus devlet olarak kurulan Türkiye'nin yeni rejimi, Osmanlı'dan kopuşu ortaya koyuyordu. Ancak Türk toplumunu yeni döneme, anlayışa ve rejime adapte etmek kolay bir iş değildi. Cumhuriyet Halk Partisi'nin hem iktidarını ve yeni rejimi meşrulaştırmak hem de toplumsal birlikteliği sağlayabilmek için birtakım sembollere ihtiyacı vardı. Milli bayramlar bu sembollerin belki de en önemlisiydi. Bu durumun bilincinde olan iktidar, yeni gelenekler icat etme çerçevesinde hemen harekete geçti ve ilk yıllardan itibaren çeşitli özel günler belirlemeye başladı. Hiç kuşku yok ki üretilen özel günler

Turkish Studies, 16(2) 
arasında en önemlisi Cumhuriyet Bayramı idi. Bilindiği üzere 29 Ekim günü ilk olarak 1924'te kutlandı; 19 Nisan 1925 tarihli yasal düzenlemeyle de "Milli Bayram" olarak kabul edildi ve her yıl kutlanmaya devam edildi. Cumhuriyet Bayramı, yeni kurulan rejimi kurumsallaştırma işlevi görmekle kalmayacak; yeni siyasal formasyonun yeniden üretilmesi için gerekli meşruiyet ortamını da sağlayacaktı. Bundan dolayı 1930'lu y1llara gelindiğinde kutlamalardaki söylem bir envanter mahiyetindeydi. Tespitlerimize göre, on beşinci yıl dönümü kutlamalarını organize etmek üzere Şükrü Kaya başkanlığında bir "Yüksek Komisyon" oluşturulmuştu. Tabi Başkent kutlamalarının ayrı bir yeri ve önemi vardı. Çünkü Başkent kutlamaları hem diğer illere örnek oluşturacaktı hem de içe ve dışa yönelik verilmek istenen mesajların daha rahat ulaşmasını sağlayacaktı. Belirlemelerimize göre, Atatürk'ün rahatsızlığından dolayı katılamadığı bu ilk Cumhuriyet Bayramı kutlamalarında mekânsal bağlamda milli egemenliğin tecelli ettği TBMM, hipodrom, Ulus Meydanı ve Zafer Anıtı ile Cebeci Şehitliği ön plana çıkmaktadır. Törensel bağlamda ise TBMM'de düzenlenen kabul töreni, hipodromda herkesin katıldığı ve en gösterişli etinliklerin yapıldığı geçit töreni, kentin en uğrak yeri olan Ulus Meydanında yer alan Zafer Anıtı'ndaki bağlılık yemini ve Türk gençliğinin Cebeci Şehitliği'nde minnettarlıklarını ifade ettiği etkinlikler öne çıkmaktadır.

Anahtar Kelimeler: Atatürk İlkeleri ve İnkılâp Tarihi, Ankara, Cumhuriyet Bayramı, milli bayram, Türkiye Cumhuriyeti, 29 Ekim 1938, on beşinci yıl dönümü kutlamaları

\section{Giriş}

Tarihsel süreç içerisinde önem atfedilerek ayin, tören, festival ve bayram şeklinde ifade edilen özel günler, toplumların ortak hatıralarına ve/veya yaşanmışlıklarına dayanmaktadır. Söz konusu günler ekonomik, dini, siyasal ve toplumsal bağlamlarda ayrı ayrı önemlere haizdir. Bununla birlikte ayinden milli bayrama doğru hem içerik hem de zamansal bazda farklılıklar gösteren bu organizasyonların değişmeyen temel işlevi, iktidarlara meşruiyet kazandırmayı hedefleyen pratikler olmalarıdır. Bilindiği üzere kuşaktan kuşağa aktarılarak varlığını sürdüren bu tür etkinlikler 19. yüzyıla gelindiğinde çeşitli siyasal, ekonomik ve toplumsal şartlara bağlı olarak ciddi değişimlere uğradı (Özbudun, 1997). Nitekim yüzyıllar boyunca iktidarlarının kaynağını Tanrı'da bulan monarklar ve doğal olarak geleneksel monarşiler, Fransız Devrimi'nden sonra derin meşruiyet krizleri yaşamaya başlamıştı (Karateke, 2009: 13). Diğer bir ifadeyle 19. yüzyıla gelindiğinde, kitlelerin siyaset sahnesine giderek artan bir oranda girmeleri, siyasal rejimlerin yönetilenler nezdinde meşruiyet sağlama ihtiyacını arttırmış, iktidarın dinsel ve geleneksel meşruiyet kaynaklarının zayıflamış olması da meşruiyetin sağlanmasında yeni araçları gerekli kılmıştı (Yamak, 2008: 324). Yeni anma törenleri, marşlar, milli bayramlar, resmî tatiller, seremoniler ve çeşitli semboller gibi ideolojik araçlar bu saiklerle üretildi (Hobsbawm, 2006: 305306). Dolayısıyla bu çalışmanın ana temasını oluşturan milli bayram olgusu, Fransız Devrimi sonrasında ortaya çıkan, toplumların yeni dünya algılarının ve ulus devlet oluşumunun bir paradigması olarak değerlendirilebilir.

Burada üzerinde durulması gereken nokta, geleneksel monarşiler ile ulus devletlerin 19. yüzyılda eş zamanlı olarak birtakım yeni gelenekler üretmiş olmasıdır. Mesela İngiltere'de bu yöndeki pratikler, kraliyet törenleri şeklinde belirginleşiyordu ve bu pratikler mümkün olan her yerde kendilerine uygun düşen tarihsel bir geçmişle süreklilik oluşturmaya çalışmaktaydı (Cannadine, 2006: 119-192). Fransa'da ise devrimciler, kraliyet sembollerinin yerine cumhuriyetçi ve laik semboller ikame etmekteydi (Idzerda, 1954: 18-19). Böylelikle geleneksel monarşiler, çağdaş monarşilere dönüşmeyi, meşruiyet açıklarını kapatmayı ve varlıklarını sürdürmeyi hedeflerken; ulus devletler ise yeni rejimleri toplumlarına benimsetmeye ve birlik-beraberliği sağlamaya çalışmaktaydılar. Dolayısıyla bu süreçte icat edilen milli günler ve bayramlar, toplumların birtakım ortak idealler etrafında bütünleşmesini ve ortak değerler geliştirmesini sağlamak amaciyla icat edildi (Yılmaz, 2012: 1148).

Bilindiği üzere Osmanlı Devleti'nin kutlama törenleri daha çok padişahların cülusları, kılıç kuşanmaları ve doğum yıl dönümleri gibi nedenlerle yapılmış ve süreç içerisinde iktidarı sembolize ederek gelenekleşmişti (Esat Efendi, 1979), fakat II. Meşrutiyet Dönemi’ne kadar tebaanın bu 
merasimlere doğrudan katılımı söz konusu olmamıştı. Bundan dolayı İmparatorluğun son döneminde törenlerin toplum üzerindeki etkileri azalmış durumdaydı ve bu durum toplumu topyekûn kapsayan milli günlerin belirlenmesi ihtiyacını doğurmuştu. Zira devlet çeşitli din, millet ve mezheplere mensup topluluklardan meydana geliyordu. Bu farklı toplulukları verili idealler etrafinda bir araya getirmek geçmişe göre bir hayli zorlaşmış, hatta imkânsız hale gelmişti. Hâl böyle iken milli bayram/milli gün gibi batı kökenli pratikler ve kutlama anlayışı, geç bir tarih olarak ele alınabilecek olan II. Meşrutiyet Dönemi'nde Türk toplumunun gündemine gelmiş oluyordu.

Devleti dağılmaktan kurtaracak ve tebaa arasındaki birlikteliği sağlayacak bir ortak değer olarak tasarlanan ilk özel gün, İkinci Meşrutiyet'in ilan edildiği 10 Temmuz 1908'dir. 10 Temmuz günü, 8 Temmuz 1909 tarihli yasal düzenlemeyle milli bayram olarak kabul edilerek, her yıl kutlanması kararlaştırıldı (Yılmaz, 2012: 1151). Böylelikle İmparatorluğun farklı unsurları arasında birlik/bütünlük duygusu ve Osmanlılık bilinci yaratılabilecekti. Buradan hareketle bayramın, kutlanmaya başlandığı 1909 yılından itibaren, İttihat ve Terakki Fırkası iktidarına ve meşrutiyet rejimine meşruiyet sağlama noktasında kendisine yüklenen görevi yerine getirmeye başladığı söylenebilir. Bunun dışında İkinci Meşrutiyet Dönemi'nde resmi olmamakla birlikte, devletin kuruluş günü olarak kutlanan İstiklal-i Osmanî Günü (Şahingöz, 1999: 194-201; Uzun, 2009: 131132), 2 Mayıs 1916 tarihinde kutlanan Çocuklar Bayramı ve ilk kez 29 Nisan 1916'da kutlanan İdman Bayramı (Alkan, 2011: 30-40) gibi yeni özel günler de üretildi.

\section{1- Türkiye'de Milli Bayram Olgusu ve Cumhuriyet Bayramı'nın İcadı}

Ulus devletler, toplumsal dinamiklerindeki farkl1l1klar nedeniyle kendilerine farkl1 dayanaklar üretmiş olsalar da bayrak, ulusal marş, ulusal kahramanlar ve/veya ulusal mitolojilerle belirlenen ortak bir simgeler sistemi yaratmışlardır. 19. yüzyıl Batı Avrupa'sında ortaya çıkan bu simgeler sistemi, kısa sürede bütün uluslaşma süreçlerinde yer bulmuştu (Özbudun, 1997: 127128). Emperyalizme karşı kazanılan Kurtuluş Savaşı'nın neticesinde kurulan Türkiye'de de çeşitli simgelerin ve sembollerin yanı sıra birtakım özel günler icat edildi. Söz konusu özel günlere ve bayramlara bakıldığında Millî Mücadele Dönemi'nde yaşanan önemli gelişmelerin ve Türkiye'deki köklü değişimi simgeleyen olayların referans kaynağı oluşturduğu dikkat çekmektedir. Bunun bir sonucu olarak da üretilen özel günler ile bağımsızlık, çağdaşlık, ulus, ulusal egemenlik, zafer vb. kavramların sembolleştirildiğini görmek mümkündür (Uzun, 2010: 109-110).

Atatürk Dönemi’nde resmi olarak kabul edilen ilk milli bayram, 23 Nisan Milli Bayramı (TBMMZC, Devre:1, Cilt: 10, s. 74; Salman Bolat, 2012: 40-41) ${ }^{1}$ Milli Saltanat Bayramı (TBMMZC, Devre: 2, Cilt: 3, s. 14-15); üçüncüsü 29 Ekim Cumhuriyet Bayram1; dördüncüsü 30 Ağustos Zafer Bayramı; beşincisi de Gençlik ve Spor Bayramı'dır (TBMMZC, Devre:2, Cilt: 24, s. 7-9; TBMMZC, Devre: 5, Cilt: 18, s. 904; Uzun, 2010: 109-123). ${ }^{2}$

Cumhuriyet Bayramı'nı yasal düzlemde ve Atatürk Dönemi özelinde, iki aşamada ele almak mümkündür. Çünkü ilk 29 Ekim etkinlikleri Cumhuriyet'in ilanının birinci yıl dönümü olan 1924 'te organize edildi. Ancak 29 Ekim'e dair henüz herhangi bir yasal düzenleme yapılmamıştı. Bundan dolayı TBMM, 26 Ekim 1924'te, kutlama organizasyonuna dair özel bir kararname yayınladı ve etkinlikler bu kararnameye göre icra edildi (BCA, 30-18-1-1, 11-48-17). 29 Ekim'in Cumhuriyet Bayramı olarak kabul edilmesi ise 19 Nisan 1925 tarihli "Milli Bayram Kanunu" isimli yasal düzenlemeyle gerçekleşti (TBMMZC, Devre: 2, Cilt: 18, s. 164-167). Böylelikle 29 Ekim günü, her yıl kutlanarak yeni rejimin değerlerini ortaya koymak, birlikteliği sağlamak, iç ve dış

\footnotetext{
${ }^{1}$ Bayram, TBMM tarafından 23 Nisan 1921'de kabul edilen iki maddelik "23 Nisanın Milli Bayram Addine Dair Kanun” çerçevesinde 1929'a değin bu isim altında kutlandı. 1929'da ise “23 Nisan Çocuk Bayramı” olarak kutlandı. 1930'lu yıllardaki yeni düzenlemelerle de "23 Nisan Ulusal Egemenlik ve Çocuk Bayramı" ismini aldı.

230 Ağustos ilk kez 1924'te kutlanmakla birlikte, 3 Şubat 1926 tarihli 'Zafer Bayramı Kanunu' ile resmiyet kazandı. 19 Mayıs günü ise 20 Haziran 1938 tarihli yasal düzenlemeyle "Gençlik ve Spor Bayramı” olarak resmiyet kazandı.
} 
kamuoyuna çeşitli mesajlar vermek suretiyle ulusal imaj oluşturma ve yeni rejimi Türk toplumuna benimsetme konularında önemli işlevler görmeye başlayacaktı.

Atatürk Dönemi'ndeki Cumhuriyet Bayramı kutlamalarının törensel boyutuyla ilgili olarak da bir dönemlendirme yapmak mümkündür ve bu tespitte 1933 yılı kutlamaları merkeze yerleştirilebilir. 1925-1933 yılları arasındaki Cumhuriyet Bayramı kutlamalarında, 1925 yılı için hazırlanan program çerçevesinde bir tablo söz konusudur: 29 Ekim günü başlayan etkinlikler Cumhurbaşkanı Atatürk'ün TBMM'deki kabul töreniyle başlayıp, resmigeçit, konferanslar, fener alayları ve balolar ile devam etmekteydi (Salman Bolat, 2012: 91).

İkinci dönem ise 1933 sonrası kutlamalar için model oluşturması boyutuyla, onuncu yıl dönümü kutlamalarıyla başlamaktadır. Zira yeni Türkiye, 1933 yılına gelindiğinde siyasi ve kurumsal boyutlarını belirli oranda tamamlamıştı. Bunu gözler önüne serebilmek için de onuncu yıl dönümüne, önceki kutlamalara nazaran büyük önem atfedilmekteydi (Doğaner, 2007: 119-143). Buna istinaden kutlama hazırlıkları bir hayli erken başladı, kutlama programı büyük bir titizlikle hazırlandı, hatta 1933 y1lı kutlamalarına özel olarak bir kutlama kanunu çıkarıldı. (Resmî Gazete, 26 Haziran 1933: 2785). Bu çerçevede ilk olarak CHF Umumi Kâtipliği tarafından 24 Nisan 1933 'te bir genelge yayınlandı. Genelgede bayram günlerinde yararlanılması hedeflenen araçlarla ilgili bütün detaylara yer verilmişti (BCA, 490.01-1150.36.1). Planlamaya göre kutlama günlerinde yazılı, görsel ve işitsel her türlü iletişim kanalından yararlanılacaktı. Bunun için yapılacak işlerin büyük boyutta, hareketli, renkli, zekâ ürünü ve anlamlı çalışmalar olması gerekiyordu (Salman Bolat, 2012: 97-120). Bu yoğun hazırlık dönemi neticesinde beklentileri karşılayacak düzeyde bir kutlama organize edildiğini ifade etmek mümkündür. Zira onuncu yıl kutlamaları, o zamana değin yapılanlar arasında en yoğun katılımlı bayram olarak ön plana çıktı. Bu yönüyle de 1933'ü takip eden kutlamalara model oldu.

$\mathrm{Bu}$ arada Cumhuriyet Bayramı'nın iktidar tarafindan ne denli önemsendiğini ortaya koyabilmek için 27 Mayıs 1935 tarihli "Ulusal Bayram ve Resmî Tatiller Hakkında Kanun”a da değinilmesi gerekmektedir. Çünkü altı maddeden oluşan kanuna göre sadece 29 Ekim günü milli bayram olarak kabul edilmekteydi. Zafer Bayramı, Ulusal Egemenlik Bayramı vb. diğer özel günler ise genel tatil günleri başlığı altında değerlendirilmekteydi (Resmî Gazete, 1 Haziran 1935: $5262)^{3}$

\section{2- On Beşinci Yıl Dönümü Kutlamaları}

28 Ekim 1938'de Başvekâlet tarafından yayınlanan kararnamede; bir süredir İstanbul'da bulunan ve tedavi edilmekte olan Atatürk'ün rahatsızlığından dolayı Ankara'ya gidemeyeceği ifade edilmekteydi. Bundan dolayı hem Cumhuriyet Bayramı kutlamalarına hem de TBMM'nin 1 Kasım'daki açı1ış törenine katılamayacaktı (BCA, 30-18-1-2, 85-94-7). Oysa Cumhuriyet Bayramı, Atatürk'ün dünyasında özel bir yere sahipti. O zamana kadar diğer kutlamaların önemli bir kısmına katılmazken, 29 Ekim kutlamalarına mutlaka katılmıştı. Sabiha Gökçen konuyla ilgili gözlemlerini şu şekilde aktarmaktadır: "Cumhuriyet Bayramı geldi mi, daha doğrusu yaklaştı mı, köşkü büyük bir heyecan dalgası kaplardı. Hiçbir bayramda Atatürk'ün bu derece neşeli, sevinçli ve yerinde duramaz bir halde olduğunu görmemişimdir. Kendisini sadece bu kutsal günün anlam ve önemine verirdi. 29 Ekim olduğunda erkenden kalkar, en özel giysilerini giyer, bunu yaparken de dudaklarından çok sevdiği türküleri eksik etmezdi (Gökçen, 1994: 223).” Çankaya Köşkü kütüphanecisi Nuri Ulusu da Atatürk'ün 29 Ekim günleri erken saatte kalktığını, salona geçerek Çankaya Köşkü çalışanlarının bayramını kutladığını ve onlara harçlık verdiğini aktarmaktadır (Ulusu, 2008: 198). Ancak Cumhuriyet Bayramı'na bu kadar önem veren ve her yıl dönümü kutlamasına mutlaka katılan Atatürk, bu sefer sadece bir bayram mesajı yayınlayabilecekti ve on

\footnotetext{
${ }^{3}$ Söz konusu madde şu şekildedir: "Ulusal bayram yalnız Cümhuriyetin ilân edildiği 29 ilk teşrin günüdür. Türkiye'nin içinde ve dışında Devlet adına yalnız o gün tören yapılır. 28 ilk teşrin öğleden sonra başlamak üzere 29 ve 30 günleri devam eder."
} 
beşinci yıl dönümü, Atatürk'ün katılamadığı ilk Cumhuriyet Bayramı olacaktı. Bununla birlikte on beşinci yıl kutlamaları için hazırlıklar çok erken bir tarihte başlamıştı ve muhtemelen Atatürk'ün kutlamalara katılamayacak derecede rahatsızlanacağı akıllara gelmemişti.

\subsection{Kutlama Hazırlıkları}

On beşinci yıl dönümü hazırlıklarına aylar öncesinde başlandı. CHP Genel Sekreterliği'nin 10 Mart 1938'de valilere ve parti başkanlıklarına gönderdiği genelgede on beşinci yılın Türk milletine ve Türkiye'ye mal olmuş devrimlere layık bir şekilde kutlanması için hemen hazırlıklara başlanması gerektiği, Ankara'da bir kutlama komisyonu kurulacağı ve bu komisyonun hazırlayacağ 1 program dâhilinde illerde de yerel komisyonlar oluşturulacağı ifade edilmekteydi (BCA, 490.01-1153.48.1). Kısa bir süre sonra da bakanlıklara gönderilen genelgede on beşinci y1l kutlamalarını organize etmek ve programı belirlemek amacıyla bir toplantı gerçekleştirileceği ifade ediliyordu (BCA,490.01-1153.47.1). Bu çağrıyı takiben yapılan toplantıda, 'Cumhuriyetin On Beşinci Yıl Dönümü Kutlama Talimatnamesi” hazırlandı ve kutlamaları organize etmek için Parti Genel Sekreteri ve İç İşleri Bakanı Şükrü Kaya başkanlığında dört kişilik bir "Merkez Komitesi" kuruldu. Aynı toplantıda Komiteye bağlı sekiz büro oluşturuldu, kutlama giderleri için de 320.000 liralık bir bütçe belirlendi (BCA,490.01-1153.48.1). ${ }^{4}$ Bu gelişmeyi takip eden günlerde on beşinci yıl dönümüne özel iki eser hazırlandı. Bunların ilki On Beşinci Yıl Kitab1, ${ }^{5}$ ikincisi ise Şeref Kitabı idi. ${ }^{6}$ Özellikle On Beşinci Y1l Kitabı, Merkez Komitesi tarafından bir hayli önemsenerek "Ana Kitap" olarak değerlendirilmekteydi. Radyo konferanslarının ve Halk Kürsüleri konuşmalarının temelini On Beşinci Yıl Kitabı oluşturacaktı. Fransızca ve Arapça dillerinde de basılan kitap, neredeyse bütün kurum ve kuruluşlara, dış temsilciliklere, hatta ülkenin en ücra köşelerine kadar gönderildi (BCA, 490.01-1152.44.1; BCA, 490.01-1155.1.195; BCA, 490.01-1155.56.1).

Kutlamalarda bütün toplumu kuşatacak ve önemli mesajlar içerecek bir organizasyon hedeflenmekteydi. Her türlü iletişim aracının seferber edilmeye çalışılması da bununla ilgiliydi... Afişler, broşürler, bayraklar, destanlar, hatıra paraları, kitaplar, konferanslar, madalyalar, marşlar, pullar hazırlanması, radyo yayınları tertip edilmesi, basından yararlanılması, Halk Kürsüleri’nin kurulması ve ışıklandırmalar ile süslemeler yapılması gibi birçok iletişim yöntemine başvurulması (BCA, 490.01-1153.45.1; BCA, 490.01-1154.53.1; BCA, 490.01-1155.54.1.) bundan kaynaklaniyordu.

Bunların yanı sıra bütün yurtta uygulanmak üzere 33 maddeden ve sekiz alt başlıktan oluşan bir kutlama talimatnamesi hazırlandı. 10 Ekim'de illere ve parti başkanlıklarına gönderilen talimatnamede, törenin icra edilme şekli en ince ayrıntısına kadar anlatılmaktaydı (BCA, 490.011153.48.1)."

Sıvan'ın Arap ulusalcılığının simgesel eylemlerini incelediği çalışmasında ifade ettiği gibi: "Fransız, Alman, İtalyan ve ardından Sovyet modellerini izleyen bu ayinlerin uygulanış tarzı, aşağı yukarı özdeştir: Askeri geçitler, iyi yapılanmış halk gösterileri, afişler, slogan ve marşlar, ses-1şık gösterileri, kutsal yer sayılan anıtlar ve belirtmeye gerek yok, devlet basını ve görsel işitsel medyadan bolca yararlanış" (Sıvan'dan aktaran: Özbudun, 1997: 128).

Ülke genelinde etkili kutlamalar yapılması için en ince detayların bile düşünüldüğü ve görüşülerek karara bağlandığı süreçte başkent kutlamaları ayrı bir öneme sahipti. Sonuçta en

\footnotetext{
${ }^{4}$ Bürolar şunlardı: Süsleme ve Işıklama Bürosu, Propaganda Bürosu, Neşriyat ve Afiş Bürosu, Sahne, Film ve Plâk Bürosu, Söz Bürosu, Müzik Bürosu, Sergi Bürosu ve Dişta Kutlama Bürosu.

${ }^{5}$ Onuncu Yıl Nutku ile başlayan eserde, 'On Beş Yılın Kronolojisi' başlığı altında 1919-1938 yılları arasında yaşanan önemli olaylar aktarılmaktadır. Türkiye, TBMM, CHP ve Halkevleri hakkında kurumsal bilgiler verildikten sonra da bütün bakanlıkların faaliyetlerine yer verilmektedir. Cumhuriyet Halk Partisi (1938). On Beşinci Yll Kitabı. Cumhuriyet.

${ }^{6}$ Kitap, Kültür Bakanlığı'nın çalışmaları neticesinde ilk, orta ve ögretmen okulları, sanat, ticaret, yabancı ve azınlık okullarıyla, lise ve kız enstitüleri öğrencileri arasında yapılan yazı yarışması sonucunda oluşturuldu. Eser, okul çağındaki çocukların ve gençlerin Cumhuriyet rejimi ve Atatürk ile ilgili düşüncelerini kaleme döktükleri yazılardan oluşmaktadır. Cumhuriyet Halk Partisi (1938). Şeref Kitabl. Cumhuriyet.
} 
kapsamlı kutlamalar burada icra edilecekti. Üst düzey devlet erkânı, siyasiler, bürokratlar, yabanc1 temsilciler, yerli ve yabancı basın mensupları Ankara'daki törenlere katılacak ve kutlamaları gözlemleyeceklerdi. Dolayısıyla başkent kutlamaları bir yandan ülkenin diğer kısımları için örnek oluşturacak, diğer yandan da Türkiye'nin modern görünümünü dünyaya servis edecekti. Bu çerçevede parti genel merkezi, bakanlıklar, belediye, valilik ile ilgili kurum ve kuruluşlar kutlama hazırlıklarını yürütmekteydi.

Hazırlıklar arasında Türkkuşu mensubu gençlerin, izcilerin ve deniz taburunun Başkent'e getirilerek provalara başlamış olması, dikkat çeken ilk gelişmelerdir. Merkez Komitesi'nin koordinasyonunda Türkkuşu uçaklarının geçit törenine katılması ve paraşüt atlamalarının yapılması öngörülmekteydi. Ayrıca karadan yapılacak geçit törenine Türkkuşu'na mensup dört yüz civarında gencin katılması planlanmaktaydı. Bu arada Türkkuşu'nun Ankara'da gerçekleştireceği gösteriyi de Sabiha Gökçen organize etmekteydi (Ulus, 15.10.1938; Ulus, 28.10.1938). ${ }^{7}$

Başkent kutlamalarına katılacak olan izciler de 21 Ekim günü itibariyle şehre gelmiş bulunuyordu. Çeşitli illerden gelen izciler, Ankaralı izciler tarafindan karşılanarak Ankara Lisesi, Sanat Okulu ve Gazi Lisesi'ne yerleştirilmişlerdi (Ulus, 22.10.1938). 21 ilin 35 okulunu temsil etmek üzere iki bin izci Ankara’ya gelmiş bulunuyordu (Ulus, 25.10.1938). Törenlere katılmak üzere Ankara'ya gelmesi öngörülen bir diğer grup da denizcilerdi. Bu çerçevede yürütülen birtakım yazışmalardan sonra da bir deniz merasim taburu Başkent'e geldi (BCA, 30-18-1-2, 84-89-17; Ulus, 25.10.1938).

Geçit töreniyle ilgili bu hazırlıkların yanı sıra Merkez Komitesi’nin üzerinde durduğu konulardan biri de kutlama günlerinde yapılacak radyo yayınlarıydı. Bu amaçla radyoda yayınlanacak olan konferansların konu başlıklarını belirlemek için mayıs ayı itibariyle çeşitli kurum ve kuruluşlarla bir dizi yazışma gerçekleştirilerek fikir alışverişinde bulunuldu (BCA, 490.01-1153.47.1; BCA,490.01-1153.45.1). Söz konusu yazışmaları takiben radyo konferansları için bir program oluşturuldu ve bu program, "Cümhuriyetin XV. yıl dönümü bayramı günlerinde Ankara Radyosunun neşriyat proğramı" ismiyle broşür olarak basıldı (BCA, 490.01-1153.45.1; BCA, 490.01-1153.47.1).

Merkez Komitesi, Halk Kürsüleri’nden (Uzun, 2010) de yararlanmayı hedeflemekteydi. Bu çerçevede CHP İl Başkanlığı, basın aracıllğıyla yaptığı çağrılarda; bayram günlerinde Ulus Meydanı'nda bir Halk Kürsüsü kurulacağını ve kürsünün herkese açık olacağını belirtmekteydi. Çağrıya göre; isimlerini önceden belirtmek şartıyla, 18 yaşını tamamlamış olan kadın-erkek bütün yurttaşlar kürsüde konuşma yapabilecekti (Ulus, 24-25-26-27.10.1938). Böylelikle radyo konusunda olduğu gibi Halk Kürsüleri konusunda da kutlamalardan önce birtakım belirlemeler yapılmış ve bayram günlerinde Ulus Meydanı'na kurulan kürsüde Türkiye'de çeşitli alanlarda yaşanan gelişmelerin anlatılması için bir platform hazırlanmış oluyordu.

Hazırlıkların tüm hızıyla devam ettiği günlerde süsleme ve 1şıklandırma çerçevesinde gerekli hazırlıklar tamamlanmışve 24 Ekim itibariyle de okullarda Cumhuriyet rejimiyle ilgili konferanslar verilmeye başlanmıştı (Ulus, 25.10.1938).

Ankara halkını da büyük bir heyecan sarmış durumdaydı (Ulus, 29.10.1938). ${ }^{8} 29$ Ekim'e yaklaşıldığı günlerde Ankara; halkıyla ve yerel yönetimiyle bayrama hazırdı. Ancak kutlamalarla

\footnotetext{
${ }^{7}$ 15-16 Ekim itibariyle Sabiha Gökçen'in gözetiminde provalara başlayan Türkkuşu mensuplarının büyük bir alay teşkil edecek kadar dolgun bir kadro ile geçit törenine katılması hedeflenmişti. Türkkuşu Genel Direktörlüğü de havacı gençler için çok cazip ve göz alan yeni bir tören kıyafeti belirlemişti. Kıyafet beyaz tulum, beyaz iskarpin ve beyaz başlıktan oluşmaktaydı. Şubesi bulunan bütün illerde gösteriler yapacak olan Türkkuşu'nun Başkent’teki etkinlikleri için öncekilerden daha detaylı ve zengin bir program hazırlanmıştı. Geçit töreni sırasında kız ve erkek yüz kadar paraşütçü atlama gerçekleştirecek; Türkkuşu filoları devamlı olarak şehrin semasında dolaşacak ve geçit törenine dört yüzü aşkın bir kanatlı tabur katılacakt1.

${ }^{8}$ Kemal Zeki Gençosman'ın ifade ettiği gibi; “bayrak bayrak bayrak her taraf bayrak” içindeydi. Sümerbank'ın bir fabrikası uzun süredir sadece bayrak üretmekteydi; Yerli Mallar Pazarı Müdürü, Feshane'nin aralıksız bir şekilde bayrak
} 
ilgili ciddi bir programa veya talimatnameye de ihtiyaç vardı. Zira Ankara için özel bir program da hazırlanmış durumdaydı. Program bütün detayları içeren oldukça net ve anlaşılır bir içerikten oluşmaktadır. Birinci kısmında on beşinci yıl dönümü kutlamalarının 28 Ekim günü saat 13.00'da başlayarak 30 Ekim günü saat 24.00'a kadar devam edeceği, bundan dolayı da şehrin süsleme ve aydınlatma işlerinin 28 Ekim günü saat 12.00'a kadar tamamlanmış olması gerektiği ifade edilmektedir.

İkinci kısımda 28 Ekim günü etkinlikleri sırasıyla ele alınmaktadır. Buna göre; diğer illerden Ankara'ya getirilen izciler, Türk gençliği adına saat 13.00'da Ulus Meydanı'na gidecek ve Zafer Anıtı'nın etrafında nizami olarak yerlerini aldıktan sonra saygı duruşunda bulunacak ve Anıt'a çelenkler bırakacak. Bunu müteakip İstiklal Marşı okunacak, görevlendirilen öğrenciler tarafından konuşmalar yapılacak ve en son Atatürk'e ve Cumhuriyet rejimine bağl1lık andı içilecek. Programın bu kısmı göz önünde bulundurularak bir değerlendirme yapılacak olursa, kutlamalarda öncelikli olarak gençlerin ve Zafer Anıtı'nın ön plana çıkarıldığını ifade etmek mümkündür. Genç nesil ve Cumhuriyet birlikte büyüyecek ve gelişecekti...

Programın devamında Ankara Radyosu'nun daha önce belirlenmiş olan plân dâhilinde yayınlar yapacağı ifade edilmektedir. Öne çıkan kısımlardan biri de Ulus Meydanı'na kurulmuş olan Halk Kürsüsü'dür. Programa göre; CHP il teşkilatının belirlediği kişiler saat 14:00'dan itibaren Atatürk ve Cumhuriyet rejimiyle ilgili kalabalığı coşturacak konuşmalar yapacak.

Üçüncü kısımda 29 Ekim günü etkinlikleri tespit edilmektedir. Buna göre; öncelikle TBMM'de bir kabul töreni, ardından da hipodromda da geçit töreni yapılacağ durumdadır. Bu arada kabul ve geçit törenlerine rahatsızlığından dolayı İstanbul'da tedavi gören ve kutlamalara katılamayacağı duyurulan Atatürk adına Meclis Başkanı Abdülhalik Renda'nın riyaset edeceği ifade edilmekteydi. Planlamada kabul töreninin öğlen tamamlanması ve hipodromdaki geçit töreninin saat 13.00 'da başlaması kararlaştırılmıştı. Bütün Ankara halkı hipodromdaki törene davetliydi. Geçit töreni sırasıyla Hava Kuvvetlerinin, Türkkuşu mensuplarının, izcilerin ve askeri kıtaların gösterilerine sahne olacaktı. Geçit törenini müteakip, gündüz merasimi sona erecekti. Bu arada Ankara Radyosu daha önce belirlenmiş olan plânlama dâhilinde gün boyunca yayın yapmaya devam edecek, Ulus Meydanı'ndaki Halk Kürsüsü ise geçit töreninin yapıldığı saatler haricinde saat 10.00 ile 20.00 arasında faaliyette bulunacaktı. On beş yıl önce Cumhuriyet'in ilan edildiği saatte (20.30) de İstasyondaki tepeden toplar atılacak ve top seslerini duyan ahali bir dakikalık saygı duruşunda bulunduktan sonra İstiklal Marşı'nı okuyacaktı.

Son kısımda ise 30 Ekim gününün planı yer almaktadır. Buna göre; izciler saat 12.30 'da Samanpazarı'ndan hareket ederek Hamamönü yoluyla Cebeci Şehitliği'ne gidecekti. Ardından şehitliğe çelenk bırakacak, saygı duruşunda bulunacak ve İstiklal Marşı'nı okuyarak etkinliği sonlandıracaklardı. Bu arada Ankara Radyosu yayınlarına, Halk Kürsüsü de faaliyetlerine devam edecekti (Ulus, 28.10.1938).

\subsection{Ankara Kutlamaları: "Büyük Bayram"}

28 Ekim günü saatler 12.00'1 gösterdiğinde Başkent baştan başa süslenmiş, kutlamalar için hazır hale getirilmiş durumdaydı. Her tarafa vecizeler içeren bez dövizler ile Türk bayrakları asılmış, çeşitli panolara afişler yerleştirilmiş, binalar süslenmiş, şehrin her tarafı 1şıklandırılmış, Ulus Meydanı'na da bir Halk Kürsüsü kurulmuştu (Unat, 2019). Bu arada sabah saat 10.00'da Radyo İstasyonu'nun açılışı büyük bir törenle gerçekleştirilmiş̧i. Açılış töreninde Meclis Başkanı Abdülhalik Renda ile Bayındırlık Bakanı Ali Çetinkaya vd. yetkililer yer almıştı (Ulus, 29.10.1938). Artık sıra etkinliklerin başlamasına gelmişti.

ürettiğini ifade ediyordu; seyyar satıcılar da bayrak yetiştiremediklerini belirtiyorlardı. Ankara halkının bayram hazırlığı sadece bayrak alımından da ibaret değildi. Bayram haftasında Ankara piyasasında şapka, elbise ve ayakkabı satışlarında yüzde elli artış olmuştu.

Turkish Studies, 16(2) 
Başkent kutlamaları, ülke genelinde olduğu gibi, 28 Ekim günü saat 13.00'da başladı. İzciler ve öğrenciler programda belirlendiği üzere, Ankara Erkek Lisesi'nden çıkış yaparak Denizciler ve Anafartalar caddeleri yoluyla Ulus Meydanı'ndaki yerlerini almış bulunuyordu. Tören izcilerin yanı sıra Veteriner, Ziraat ve Binicilik okulları öğrencilerinin katıldığı ve Zafer Anıtı'nda gerçekleştirilen yemin töreniyle başladı. Anıt'a çelenk bırakan öğrenciler, Atatürk'e ve Cumhuriyet rejimine bağlılık yemini ettikten sonra da meydanda toplananlarla birlikte İstiklal Marşı'nı okudular (Son Telgraf, 29.10.1938). Cumhuriyet gazetesinin aktardığına göre, izciler ve diğer katılımcılar törenden sonra marşlar söyleyerek Ankara sokaklarını dolaşmak suretiyle ahalinin arasına karışıyordu (Cumhuriyet, 29.10.1938).

Bu esnada kutlamaların organizatörü olan İçişleri Bakanı Şükrü Kaya, Zafer Anıtı'nın önüne gelerek kutlamaları açış mahiyetinde bir konuşma yaptı. Kaya konuşmasına Birinci Dünya Savaşı'nın doğurduğu sonuçlar, Anadolu'nun işgali, İstanbul yönetiminin teslimiyetçi tavrı ve Kurtuluş Savaşı'na değinerek başladı. Yönetim anlayışı, uygulamaları ve savaş yıllarındaki teslimiyetçi anlayışından dolayı Osmanlı rejimini eleştiren, hatta suçlayan İçişleri Bakanı, sözü Atatürk'e ve Cumhuriyet rejimine getiriyordu. Atatürk'ün 1920'de TBMM'yi açmak suretiyle Türk milleti için ideal olan Cumhuriyet rejiminin temellerini attığını ve milli iradenin tezahür etmeye başladığını vurgulamaktaydı. Cumhuriyet rejiminin on beş yılda Türkiye'ye neler kazandırdığını anlamak için çok fazla düşünmeye gerek olmadığını ifade eden Kaya, bunu anlayabilmek için 1938 Türkiye'sine ve Türk milletinin mevcut durumuna bakmanın yeterli olacağını vurgulayarak, nutkunu şu şekilde sonlandırıyordu:

“...Biz bu inkılabı, bu rejimi yalnız Türk milletinin istiklali refahı ve menfaatı için değil aynı zamanda medeniyetin ve cihan sulhünün ilerlemesi ve korunması için Atatürk'ün emrinde ve izinde tutmaya, yükseltmeye, yürütmeye borçluyuz. Var ol Atatürk, sana sonsuz bağlllık ve minnet" (Yeni Sabah, 29.10.1938).

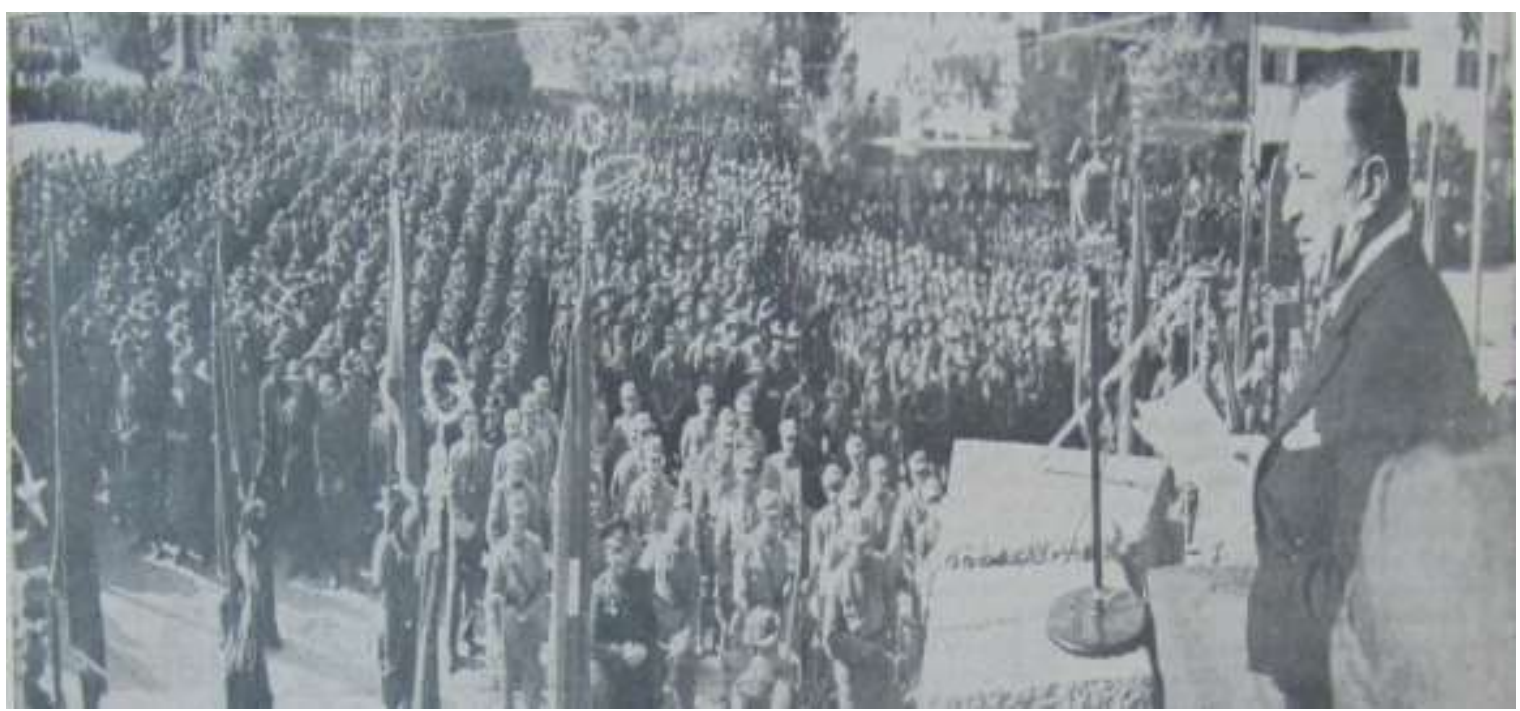

Cumhuriyet, 30 Ekim 1938

Konuşmanın geneline bakıldığında bir yandan eski rejimin olumsuz yanlarının vurgulandığı, diğer yandan da Atatürk'ün ve Cumhuriyet rejiminin yüceltildiği dikkat çekmektedir. $\mathrm{Bu}$ açıdan nutkun doğrudan geleneklerin icadına uygun bir içeriğe sahip olduğunu belirtmek mümkündür. Zira milli bayram gibi icat edilmiş geleneklerin amaçları arasında eskiyi devre dışı bırakarak izlerini silme ve yeni yapıyı yücelterek meşruiyet zemini oluşturma, toplumu da bu yapının etrafında birleştirme anlayışı yatmaktadır. 


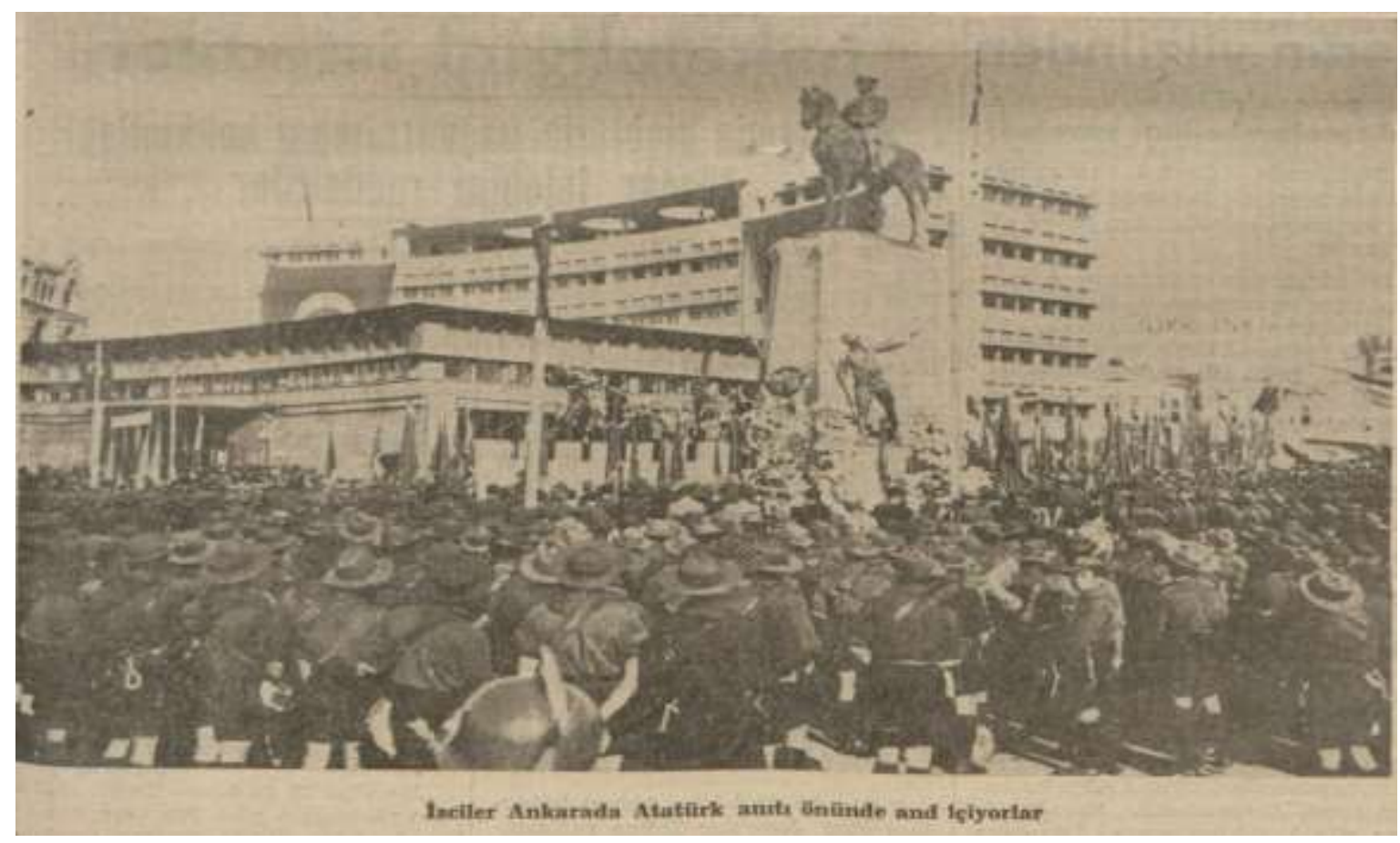

Cumhuriyet, 30.10.1938

Ankara Radyosu'nun kutlamalara yönelik yayınları da eşzamanlı bir şekilde başlamış bulunuyordu. 13:00'da İstiklal Marşı ile başlayan yayın, Ulus Meydanı'ndaki törenin nakliyle, yani öğrencilerin yemin töreni, İstiklal Marşı ve Şükrü Kaya'nın konuşması ile devam etmekteydi. 15:00 itibariyle de daha önce belirlenmiş program çerçevesinde on beşinci yıla özel olarak hazırlanmış bulunan konferanslar başladı. Bu çerçevede gün boyunca devam eden mahkemeler, Türk ordusu, köy ve köycülük, Türk Tarih İnkılabı, demiryolları, maliye ve vergiler, sağlık politikaları, Türk Spor Kurumu, milli ekonomi, Emlâk Bankası, Türk Maarif Kurumu, su işlerinin köy kalkınmasındaki önemi konulu konferanslar verildi (BCA, 490.1-1162.81.2).

Kuşkusuz kutlamalar kapsamındaki en gösterişli etkinlikler 29 Ekim günü düzenlendi. Programa göre öncelikle TBMM'deki kabul töreni icra edildi. Törende ev sahipliğini Cumhurbaşkanı adına Meclis Başkanı Abdulhalik Renda üstlendi. Dolayısıyla tebrikleri de Renda kabul etmekteydi. Tören yerli/yabancı bütün davetlilerin TBMM'ye gelmesinden sonra saat 13:00'da başladı. Kabul törenine neredeyse bütün yabancı temsilcilik görevlileri katılmıştı: Amerikan, İngiliz, Alman, Sovyet, Yunan, Afgan, Yugoslav, Romen, İran elçileri ile elçilik çalışanları ve diğerleri TBMM'deydi (Akşam, 30.10.1938).

Meclis'teki kabul töreninden sonra saat 14.30 'da başlayacak olan geçit töreni için hipodroma geçildi. Bu arada hipodromda inanılmaz bir kalabalık oluşmuştu. Geçit törenini izlemek isteyen Ankaralılar ve Ankara dışından gelenler günün erken saatlerinden itibaren tribünlerdeki yerlerini almış bulunuyordu. Ulus gazetesi geçit törenine yaklaşık olarak yüz bin kişinin katıldığını aktaracakt1 (Ulus, 30.10.1938).

Hipodromdaki tören İstiklal Marşı ile başladı. Geçit töreninden önce de Başbakan Celal Bayar tarafından Atatürk'ün orduya hitaben mesajı okundu. Mesaj şu şekildeydi:

“Zaferleri ve mazisi insanlık tarihi ile başlıyan, her zaman zaferle beraber medeniyet nurlarını taşıyan kahraman Türk ordusu,

Memleketini en buhranlı ve müşkül anlarda zulümden, felâket ve musibetlerden ve düşman istilâsından nasıl korumuş ve kurtarmış isen Cumhuriyetin bugünkü feyizli 
devrinde de askerlik tekniğinin bütün modern silah ve vasitalarile mücehhes olduğun halde vazifeni aynı bağlılıkla yapacağına hiç şüphem yoktur.

Bugün, Cumhuriyetin 15'inci yılını mütemadiyen artan büyük bir refah kudret içinde idrak eden büyük Türk milletinin husurunda kahraman ordu, sana kalbi şükranlarımı beyan ve ifade ederken büyük ulusumuzun iftihar hislerine de tercüman oluyorum.

Türk vatanının ve Türklük camiasının şan ve şerefini dâhili ve harici her türlü tehlikelere karşı korumaktan ibaret olan vazifeni her an ifaya hazır ve amade olduğuna benim ve büyük ulusumuzun tam bir inan ve itimadımız vardır. Büyük ulusumuzun orduya bahşettiği en son sistem fabrikalar ve silahlarla bir kat daha kuvvetlenerek büyük bir feragati nefs ve istihkarı hayat ile her türlü vazifeyi ifaya müheyya olduğunuza eminim. Bu kanaatla kara, deniz, hava ordularımızın kahraman ve tecrübeli komutanlarile subay ve eratını selamlar ve takdirle bütün ulus müvacehesinde beyan ederim. Cumhuriyet bayramının 15'inci yıldönümü hakkınızda kutlu olsun" (Kurun, 30.10.1938).

Mesaj içerik açısından bir hayli önemli. Bilindiği üzere Atatürk en başından itibaren 1937 y1lı dâhil olmak üzere bütün Cumhuriyet Bayramı kutlamalarına katılmıştı ve sadece onuncu yıl dönümü kutlamalarında meşhur Onuncu Yıl Nutku'nu okumuştu. Diğer yıl dönümlerinin hiçbirinde ise herhangi bir konuşma yapmamış veya mesaj yayınlamamıştı. On beşinci yıl dönümü kutlamalarına katılamayacak olduğu için mesaj yayınlama gereği hissetiği aşikâr. Ancak mesaj, neden Türk milletine değil de orduya hitaben kaleme alınmıştı? Açıkçası elimizde buna dair herhangi bir veri bulunmamaktadır. Fakat hem dönemin uluslararası gelişmelerinden hem de tanıkların bu konuyla ilgili aktardıklarından hareketle bir değerlendirmede bulunabiliriz. Kutlama mesajının hazırlanmasıyla ilgili olarak iki tanıklık bulunmaktadır. İlkinde Kılıç Ali, kutlamalara katılamayacağı için üzgün olan Atatürk'ün hem bayram mesajını hem de 1 Kasım'da gerçekleșecek olan Meclis'in açış konuşmasını Başbakan Celal Bayar'a dikte ettiğini aktarmaktadır (Turgut, 2008: 648). İkinci tanıklıkta ise Hasan Rıza Soyak, kutlama mesajının Atatürk ile Genelkurmay Başkanı Fevzi Çakmak tarafından hazırlandığını belirtmektedir (Soyak, 1973, C. II: 768). Açıkçası Soyak'ın tanıklığı ile metnin içeriği daha uyumlu görünmektedir. Zira bilindiği üzere on beşinci yıl dönümü, İkinci Dünya Savaşı'nın ayak seslerinin iyice hissedildiği günlerde kutlanmaktaydı. Avrupa uzun bir süredir teyakkuzdaydı ve Türkiye de dâhil olmak üzere herkes savaşa yönelik ciddi hazırlıklar içerisindeydi. Dolayısıyla ordular çok önemliydi. Bundan kaynaklı Atatürk'ün kutlama mesajını doğrudan Türkiye'nin ve Türk milletinin koruyucusu pozisyonundaki orduya hitaben hazırladığ 1 düşünülebilir. Tehlikenin farkında olan Atatürk, bu kutlama mesajıyla orduya olan güvenini ortaya koymakta ve orduyu her türlü tehlikeye karşı hazırlıklı olma konusunda motive etmekteydi. Bunun yanı sıra muhtemelen Türk milletinin orduya olan güvenini de tazelemeyi hedeflemekteydi. Kutlama mesajının Atatürk ve Genelkurmay Başkanı Fevzi Çakmak tarafından hazırlanmış olması da bunun bir göstergesi olarak değerlendirilebilir.

$\mathrm{Bu}$ arada Başbakan Bayar'ın konuşmasından sonra geçit töreni başlamıştı. Savaş uçaklarının gösterisiyle bașlayan tören sırasıyla izcilerin geçiși, Türkkuşu öğrencilerinin parașüt atlayışı ile denizcilerin, süvarilerin, topçuların ve karacıların renkli etkinlikleriyle devam etti (Son Posta, 30.10.1938). 


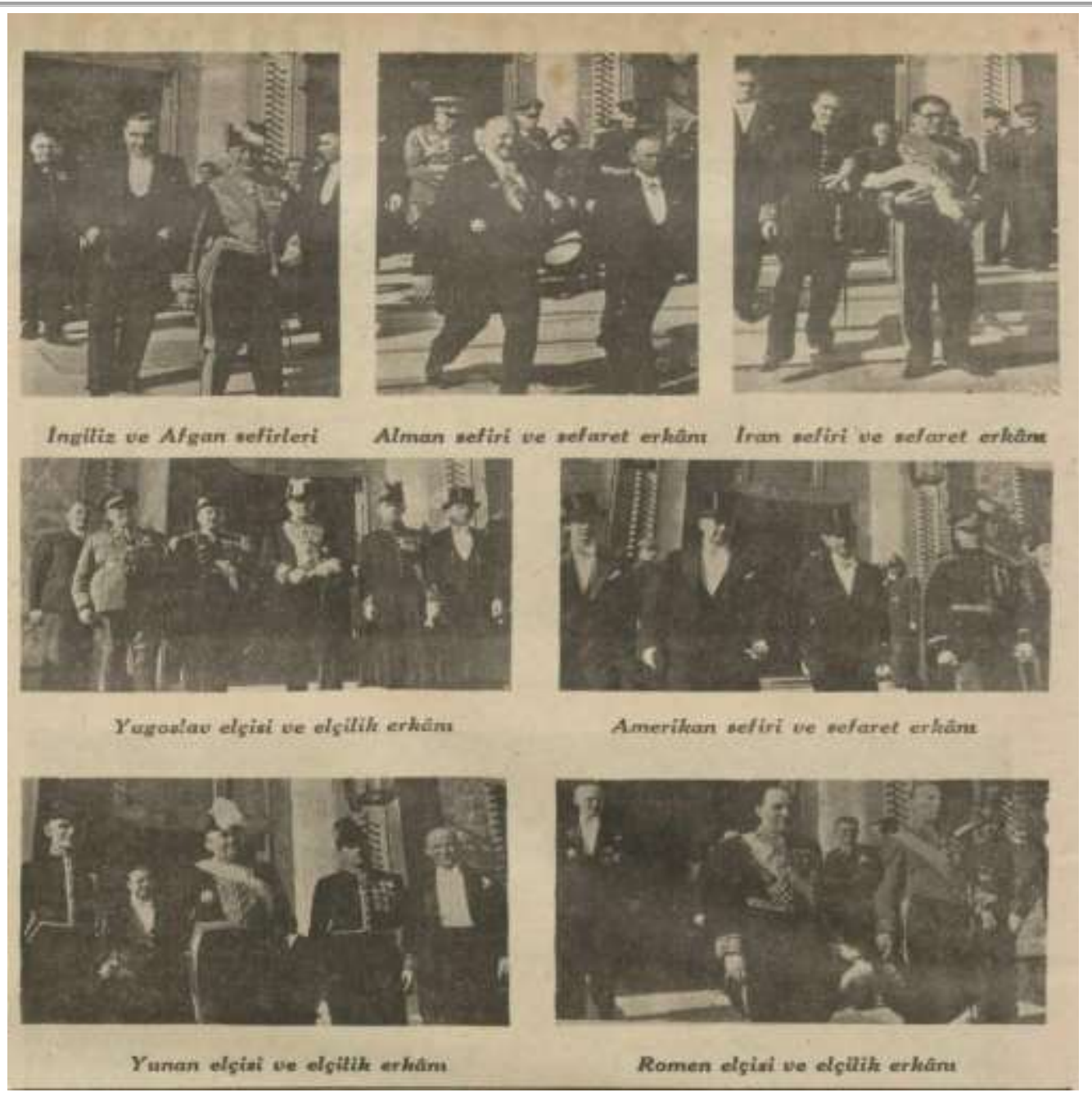

Ulus, 30.10 .1938

Hipodromdaki tören biterken, Ankara'nın diğer kısımlarındaki kutlama etkinlikleri tüm hızıyla devam etmekteydi. Sabah saat 09.00'dan itibaren başlamış olan radyo konferansları aralıksız verilmekteydi. Ziraat Bakanı Faik Kurdoğlu "Köy Kalkınmasında Ziraat Vekâleti ve Ziraat Politikamız" başlıklı konuşmasında:

"Köylü sen bu memleketin temelisin, Cumhuriyet 15 yıldır, herşeyi senin için, seninle ve senin dileğinle yapmıştır. Yol, demiryol, emniyet, asayiş, kötü vergileri koparıp atma, bataklık ve kuraklıklarla savaş, sağlam politika, fabrika, kanunlar... Hep hep senin saadetin için, seni layık olduğun ve istediğin mesut yaşayışa eriştirmek, önündeki fena şartları, vasıtasızlıkları, imkansızlıkları süpürüp atmak için düşünülüp hesaplanmış, sıraya konup başarılmış şeylerdir. Bugün önünde geniş, ferah, binlerce imkânla dolu bir yol var."

diyordu. Dışişleri Bakanlığı adına konuşma yapan Nebil Batı ise "Türkiye'nin kuvveti cihan sulhu için lazımdır"diyerek Türkiye'nin uluslararası politikadaki önemine vurgu yapmaktayd1 (Cumhuriyet, 30.10.1938). Radyo konferansları bunlardan ibaret değildi. Gece geç saatlere kadar meteoroloji, sağlık, bayındırlık, Türk Hava Kurumu, Merkez Bankası, Ziraat Bankası, İş Bankası, Eti Bank hukuk, yerel yönetimler ve şehircilik, demiryolları, borçlar ve ekonomik yapı ve iç-dış ticaret gibi konularla ilgili 10-15 dakikalık birçok konferans verildi (BCA, 490.01-1162.81.2). 
Ulus Meydanı'na kurulmuş olan Halk Kürsüsü de erken saatte faaliyetlerine başlamış bulunuyordu. Önceden isimlerini yazdıran vatandaşlar akşam saat 20.00'a kadar kürsüden çeşitli konuşmalar yaptı (Ulus, 30.10.1938). Tam bir bayram havasının hâkim olduğu Ankara'daki etkinlikler, gece geç saatlere değin davam etti. Bütün sokaklar ve meydanlar doluydu. Ankara Kalesi'ne yerleştirilen büyük projektörlerle her yer aydınlatılmış durumdaydı. Ara sıra yapılan havai fişek gösterileri ve 1şı gösterileri göz alıcıydı. Ulus Meydanı, Bankalar Caddesi ve Atatürk Bulvarı'ndaki bütün binalar özenle süslenmiş ve 1şıklandırılmıştı. Ulus gazetesinin aktarımıyla; "İstasyon Caddesi kademe kademe uzanan muazzam fasılalı 1şık desteleri altında göklerin samanyolunu andiriyordu" (Ulus, 1.10.1938).

Geç saatlere kadar devam eden kutlamalara 30 Ekim sabahı kalınan yerden devam edildi. Radyo konferansları ilk iki günkü gibi erkenden başlamıştı ve gece saat 24.00'a kadar devam etti. Yine birçok konu ele alındı ve yeni Türkiye'nin çeşitli alanlardaki önemli faaliyetleri toplumla paylaşı1lı (BCA, 490.01-1162.81.2).

30 Ekim gününün törensel boyuttaki etkinliği ise izcilerin şehitliğe gerçekleştirdiği ziyaret oldu. Bu çerçevede izciler bir piyade bölüğü ile birlikte Hamamönü yolunu takip ederek şehitliğe gitmek suretiyle bir tören icra etti. Bu kapsamda bir kız ve bir erkek izci tarafından konuşmalar yapılarak sayg1 duruşunda bulunuldu, İstiklal Marş1 okundu ve çelenk bırakıldı (Akşam, 31.10.1938). Bu arada Saat 15.00 'da Cumhuriyet Bayramı'na özel bir futbol maçı yapıldı ve Demirspor, Ankaragücü’nün sahasında yapılan maçı 2-0 kazanarak "On Beşinci Y1l Dönümü Kupası"nı kazand1 (Cumhuriyet, 31.10.1938).

\section{Sonuç}

19. yüzyılın ruhuyla uyumlu bir ulus devlet olarak kurulan Türkiye'de toplumu tebaadan yurttaşa dönüştürmek kolay bir iş değildi. Diğer bir ifadeyle gelenekçi Türk toplumunu eski alışkanlıklarından, yaşam tarzlarından ve eski yönetim anlayışına olan bağlılığından koparmak zordu. Beklenti; uzun yıllar boyunca "Padişahım Çok Yaşa!" şeklinde haykıran ve bunu kanıksayan Türk toplumunun "Yaşasın Cumhuriyet" sloganları atmasıydı. Toplumsal bütünlük ve siyasal meşruiyet zemini ancak bu şekilde oluşabilirdi. Cumhuriyet Bayramı'nın icadı da tam olarak bu noktada karşımıza çıkmaktadır.

On beşinci yıl dönümünün hazırlık aşaması ve kutlamalarına dair tespit ettiğimiz etkinliklerden hareketle, yeni düzenin kutsanmasının iktidar tarafından üretilen ve yayılan siyasi semboller aracılığıyla gerçekleştirildiğini ifade etmek pekâlâ mümkündür.

Kutlama programına bakıldığında katı düzenleyici, fakat aynı zamanda birleştirici bir söylem ve organizasyon üzerinden bütün toplumsal katmanlara ulaşma çabası gözlemlenmektedir: Toplumun bütün katmanları, Cumhuriyet rejimiyle bütünleşmeye ve iktidarı desteklemeye davet edilmekteydi.

Tespitlerimize göre; TBMM-Kabul Töreni, Hipodrom-Geçit Töreni, Ulus Meydanı ve Zafer Anıtı-kapsamlı etkinlik alanı, Cebeci Şehitliği ise Türk gençliğinin minnettarlığını ifade ettiği mekân olarak öne çıkmaktadır. Kabul töreni milli egemenliğin tecelli ettiği yer olan TBMM'de, geçit töreni ise hipodromda gerçekleştirildi. Kentin en kalabalık yeri olan Ulus Meydanı ise kutlamaların merkezi olarak göze çarpmaktadır. Ve Zafer Anıtı; Türk gençliğinin, Anıt'a çelenk bırakmak ve saygı duruşunda bulunmak suretiyle Atatürk'e saygı gösterisinde bulunmaları dikkate değer bir etkinliktir. Diğer önemli mekân ise Cebeci Şehitliği; gençler şehitliğe çelenk bırakmak ve saygı duruşunda bulunmak suretiyle ülkenin kurulmasında büyük pay sahibi olan şehitlere minnettarlıklarını ifade ediyorlardı.

Kutlamalar ve etkinlikler kümülatif olarak kurucu lider Atatürk ve Cumhuriyet rejiminin faziletleri etrafinda şekillenmekte, bir toplumsal hafiza oluşturmayı hedeflemektedir. Mekânsal ve törensel tercihler de bunu açıkça ortaya koymaktadır. Kabul töreninin ulusal egemenliğin tecelli 
ettiği TBMM'de icra edilmesi, Zafer Anıtı'nın simgesel boyutunun öne çıkarılması ile Türk gençliğinin Anıt'a çelenk bırakarak Atatürk'e ve Cumhuriyet'e bağlllık yemini etmesi, bu çerçevedeki önemli göstergeler olarak ele alınabilir. Bu aynı zamanda daha hayattayken Atatürk'e dair lider kültünün oluştuğunu da göstermektedir.

Nihai olarak, evet Atatürk rahatsızlığından dolayı Ankara kutlamalarına katılamamıştı. Ancak Ankara, başkent olarak belirlendiği 13 Ekim 1923'te hayal edildiği gibi tam bir Cumhuriyet kenti görünümündeydi. Ankaralılar ve Ankara dışından gelmiş bulunanlar etkinliklere katılıyor, eğleniyor ve rejimle bütünleşiyordu. Rejim de bundan besleniyor ve güçleniyordu. Zaten 29 Ekim gününün gelenekleştirilmesi, "Büyük Bayram" olarak ifade edilmesi ve sembolleştirilmesi bununla ilgili değil miydi?

\section{Kaynakça}

\section{Arşivler}

Cumhurbaşkanlığı Devlet Arşivleri

\section{Resmi Yayınlar}

Resmî Gazete

Türkiye Büyük Millet Meclisi Tutanakları

\section{Süreli Yayınlar}

Akşam

Cumhuriyet

Kurun

Son Telgraf

Son Posta

Ulus

Yeni Sabah

\section{Telif Eserler}

Alkan, M. Ö. (2011). Osmanlı İdman Bayramı'ndan Atatürk'ü Anma, Gençlik ve Spor Bayramı'na". Toplumsal tarih, (2011), 30-40.

Cannadine, D. (2006). Ritüelin bağlamı, icrası ve anlamı: Britanya monarşisi ve geleneğin icad1, Geleneğin icadı. (Yay. Haz.) Hobsbawm, Eric\&Tereence Ranger, (Çev.) Mehmet Murat Şahin, Agora.

CHP. (1938). On Beşinci Yıl Kitabı. Cumhuriyet.

CHP. (1938). Şeref Kitabı. Cumhuriyet.

Doğaner, Y. (2007). Cumhuriyet'in onuncu yıl kutlamaları. Askeri tarih araştırmaları dergisi, (9), 119-143.

Esat Efendi. (1979). Osmanlılarda töre ve törenler (Teşrifat-ı kadime), (Sadeleştiren) Yavuz Ercan, Tercüman.

Gökçen, S. (1994). Atatürk’le bir ömür, (Haz.) Oktay Verel, Altın. 
Hobsbawm, E. (2006). Seri üretim gelenekler: Avrupa 1870-1914, Geleneğin icadı. (Yay. Haz.) Hobsbawm, Eric\&Tereence Ranger, (Çev.) Mehmet Murat Şahin, Agora.

Idzerda S. J. (1954). Iconoclasm during the French revolution, American historical review, 60 (1).

Karateke, H. (2009). Padişahım çok yaşa! Osmanlı Devleti'nin son yüzyılında merasimler. İletişim.

Özbudun, S. (1997). Ayinden törene -siyasal iktidarın kurulma ve kurumsallaşma sürecinde törenlerin işlevleri-. Anahtar.

Salman Bolat, B. (2012). Milli bayram olgusu ve Türkiye'de yapılan Cumhuriyet Bayramı kutlamaları (1923-1960), Atatürk Araştırma Merkezi.

Sivan, E. (1990). "Symboles et rituels et Arabes", Annales ESC, (4).

Soyak, H. R. (1973). Atatürk'ten hatıralar. Yap1 Kredi.

Şahingöz, M. (1999). Osmanlı'dan millî mücadeleye İstiklal-i Osmanî Günü kutlamaları, Yeni Türkiye dergisi, (1), 194-201.

Turgut, H. (Der.). (2008). Atatürk'ün sırdaşı Kılıç Ali’nin anıları. Türkiye İş Bankası.

Ulusu, M. K. (Der.). (2008). Atatürk’ün yanı başında: Çankaya köşkü kütüphanecisi Nuri Ulusu'nun hatıraları. Doğan Kitap.

Uzun, H. (2010). Bir propaganda aracı olarak Cumhuriyet Halk Fırkası Halk Hatipleri Teşkilatı, Cumhuriyet tarihi araştırmaları dergisi, (11), 59-76.

Uzun, H. (2010). Milletin iradesiyle oluşan bir bayram: Atatürk'ü Anma 19 Mayıs Gençlik ve Spor Bayramı ve Atatürk döneminde kutlanışı, Karadeniz araştırmaları, 6 (24), 109-125.

Uzun, H. (2009). Türk Yurdu'nda 1913 y1lı İstiklâli Osmanî Günü, Modern Türklük araştırmaları dergisi, 6 (1), 128-141.

Unat, K. (2019), Cumhuriyet'in on beşinci y1l dönümü afişleri üzerine bir değerlendirme, Sosyal, beşerî ve idari bililimler-2 Alanında yeni ufuklar, (Ed.) Sinan Sönmez vd. Gece, 245-261.

Yamak, S. (2008). Meşrutiyetin bayramı: 10 Temmuz Îd-i Millisi, İstanbul Üniversitesi Siyasal Bilgiler Fakültesi dergisi, (38), 323-342.

Yılmaz, M. S. (2012). II. Meşrutiyet dönemi İstanbul'unda 10 Temmuz milli bayram kutlamaları, 7. Uluslararası Türk kültürü kongresi-, bildiriler I İstanbul tarihi: Medeniyetlerin buluşma noktası olarak İstanbul, (Yay. Haz.) Suzan Gür. Atatürk Kültür Merkezi, 1145-1170. 